to transact their own affairs. The treatment accorded them must give them faith in America and Americans through dealings which bring them in actual contact with the social and business life of the community in which they reside. This treatment of all aliens on our part is essential if America is to succeed in attaining the end so devoutly desired, which was expressed in the words of President Wilson when he said:

You can not become thorough Americans if you think of yourselves in groups. America does not consist of groups. A man who thinks of himself as belonging to a particular national group in America has not yet become an American. . . America was created to unite mankind by those passions which lift.

\title{
The Political Education of the Immigrant
}

\author{
By Talcott Williams, LL.D.
}

Director, Emeritus, School of Journalism, Columbia University, New York City

$\mathrm{T}$ HE prime and perpetual difficulty in the political education of the immigrant is that he has, if an adult, already received a political education, such as it is, upon which he is certain to act. You can not do much in the way of education with most adults over twenty, except development in the line of the education already received. There is a glib notion afloatheld particularly in college settlements, by inmigration officers and those who, having handled immigrants by the thousand or not at all, feel sure that they know something about themthat schooling can easily be given the newcomer after he arrives. Schooling can be given, but the immigrant can not be schooled except as the very best training opens his mind. Take Carl Schurz: if there ever lived a man who seemed likely to become a full American, it was he. He learned our tongue. In its diction and in its supple and effective use, he surpassed most men of note on the platform. He sought the field for his adopted land in war and he nobly served it in peace. He supported every reform. He fought with the beasts in our Ephesus, the Senate, full of men given to getting great personal gain. He had suffered and lost for liberty in his own land. Yet when despotism came there, in Prussia triumphant, it had his heartiest support. For freedom crushed to earth in the new-born French Republic, he had neither pity nor mercy. The American instinct as to Europe, always for selfgovernment, he could never get. $\mathrm{He}$ forgave Bismarck in the full tide of his oppression of Poland. He accepted the Kaiser-ate and swallowed the young Emperor whole. He led a multitude of Americans astray by his abject admiration of the last of the hereditary European despotisms. Does anyone have the slightest doubt that if Schurz had been alive he would have been on the side of Germany in August, 1914, that he would have been opposed to having the United States enter the Great War, and that he would have stood an excellent chance of placing himself so far in the wrong that retreat would have been difficult when we went in? So with lesser men, most of all with men who came from lands recently emancipated or still under dire oppression.

Even the sons and daughters of the immigrants are not easy to educate politically. I was in contact with many of them when the shadow of war drew near. They believed themselves to be 
Americans in their heart of hearts; they held themselves to understand American institutions, to know the way they did work and, above all, the way they should work, far better than those whose ancestors had made these institutions and run them for three hundreds years. They all had "taken" courses in political science, but many of those who had taught them were little interested in showing where the American governing mechanism had worked well, and how much it had accomplished for the nation and for the world. These teachers were very much interested in showing how our Constitution should have been made if they had been consulted in time, how ill it had worked now and how much improved it would be if it could be re-drawn by a Federal Constitutional Convention, made up exclusively of professors of political science. This was great fun for the professor, but it was not particularly successful in imparting any practical political education to those who were just one generation removed from the barbarism, the darkness, the oppression, and, above all, the low moral standards of nearly all of Europe.

I found when war drew near that the teaching in political science which young men and women had received in some High Schools of New York City had done nothing to acquaint them with the supreme claim which the nation under American institutions had on the citizen when war comes upon the land and the loyal service due the majestic might and embattled will of the American people when, through its appointed agents, it draws the sword and mammon departs until victory is won. Yet when the call came, these youth nobly responded. None saw that inspiring change but saw anew the need of political education for the immigrant, the certainty that the second genera- tion could be made over in the image of the true America and that this could best be done by penetrating the American home with the American language. At that great crisis, how great verse stirred youth.

The one concrete political education which can be successfully and effectively given the immigrant is a knowledge of our national tongue: the capacity to speak the language, to read it, to write it and what is still harder to secure, to understand it. In political action nothing can make up for this loss. Wherever there is in the United States a group of people who have not learned English, there is a dead spot and a non-conducting point in the nation. This is the first and most necessary step in political education and until it is taken, peril environs not only the immigrant in his political action, but the nation itself. This was true in the Colonial period; it remains true to this day.

Night schools have been organized as a remedy. For the self-sacrificing labor of the teachers in these schools, wherever they are, I have profound respect as a teacher, and deep gratitude as a citizen. I know no place where so much work is done with so sincere a desire to improve the citizenship of the United States as in these night schools and in college settlements. The difficulty is that attendance on both is voluntary. If you will go to the trouble in regard to any college settlement of finding out how large a population is within its radius of normal action, and how small a share visit it, you will realize that the college settlement, like the mission station abroad, unless those who work in it are singularly penetrating, actually takes hold of the lives of a very small fraction of the community with which it deals. The night schools of our cities in particular, in spite of the high devotion of those 
who teach in them, are in most cases-in nearly all-poorly equipped, attendance is irregular and, after the first dash of enthusiasm, the work is slack except in the case of a few capable souls who overcome all obstacles. Massachusetts has taken the first step which looks toward compulsory education in these schools. In the end, if we are really to educate politically our future fellow citizens, the learning of American must be made compulsory. This must be secured by compulsory attendance and the schools themselves must be placed on an entirely new basis. The one great advantage which the original immigrants to the United States had was that they spoke English to begin with.

The conscious political education of the immigrant began in the cabin of the Mayflower. The Jamestown immigrants had discovered that it was awkward, expensive and insufficient to be governed from London. New Amsterdam immigrants made a like discovery as to old Amsterdam's supervision. From the first landing, every Latin immigrant suffered from being governed across the Atlantic. Latin immigrants, however, postponed action on this discovery for two centuries and they are still paying for their long and disastrous delay.

On the Mayflower, 102 immigrants faced this problem before they landed. Half of them were adult men. They met and agreed to govern themselves. To use an Australian phrase, unfortunately less popular there than half a century ago, "they cut the painter." In their "compact," those on the Mayflower accepted in theory the rule and authority "of our dread Soueraigne Lord King James"; but only as a means not an end, as presenting a sovereignty in whose name they could act, but their action was to be their own, free from control and direction. They not only asserted the right to selfgovernment, they exercised the right. They hung one of their own original members, a companion of the Mayflower, when he committed murder, and had been convicted of the same by a jury of his peers. They waited for no man to define their rights. They assumed them and acted under them; executed them and enforced them. They covenanted and combined themselves together "into a civill body politick." By "vertue hearof" they proposed "to anacte, constitute and frame such just and equall lawes, ordinances, acts, constitutions and offices from time to time as shall be thought most meete and convenient for ye generall good of ye Colonie."

This political self-education of the immigrant began the American ideal, principle and practice of self-government. The Plymouth Compact and Covenant laid the foundation of that government of the people, by the people and for the people whose lasting triumph was recorded in the Gettysburg address. From this seed sown in the cabin of the Mayflower, there succeeded step by step all that came after, until the Federal Union was achieved. Each colony contributed its share in turn, but the first conscious training in self-rule began in Plymouth as the selfconscious act of the Pilgrim.

The Pilgrim was able to achieve this political self-education because he was a Man of the Spirit. The little band of the Mayflower had for years thought much on the immediate spiritual relations of God and man. They believed in the Father of Spirits and they believed all His created spirits were equal under him, responsible, sovereign, selfgoverning. Their self-education came from what they were and not from what they did. The failure of the immigrant in self-government is due not 
to what is about him of neglect and the failure of others to enlighten, educate and train him, but in his own failure to awake to his own spiritual equality, liberty and sovereignty. You can not make good this lack by mere studies, lessons and courses in political science. The majesty of the state must find and kindle a spiritual majesty in the soul of every citizen or the state itself will rest on the shifting sands of personal desire, personal profits and personal ends and when on such a house the rain descends, and the floods come and the winds blow and beat upon that house, it will fall and great will be the fall thereof.

This was as true in the days of the Pilgrims of Plymouth as it is today. They were not alone in hungering and thirsting in the wilderness for the manna of liberty and the strong meat of justice and self-rule through law. New York and Virginia had their rebellions, but while Captain Leisler began "for the security of the province" he ended with "an attempt to smuggle in wines," "did in a seditious manner stir up the meanest sort of the inhabitants and had the support of those that appeared in arms Drunk and cryed out they disowned all manner of government." So Mr. Bacon of Bacon's Rebellion in Virginia was "a very hard drinker and it is reported that he dyed by imbibing or taking in two much brandy." There are still men, even on Manhattan Island, seeking to build government and carry on the political education of the immigrant by a like policy and a similar practice continued into our own day.

The quietism of the Friend and the pietism of the Mennonite in Pennsylvania worked evils as serious in the political education of the immigrant. They were not free indeed of "imbibing or taking in two much brandy"; but the passive submission of the Quaker, his readiness to bargain each year for the legislation he desired and the isolation through language of Dunker, Mennonite and even Moravian, left each the easy prey of the venal legislation and boss control of Pennsylvania. It was long perpetuated by the descendants of immigrants who had the means and the readiness to buy profitable legislation of corporate advantage, aided by those isolated by tongue and come from an oppressive tradition. These conditions steadily improve and have already lost the open venal character of the past as education brings one tongue and one political consciousness to the state. An ignorant, immigrant population is still the stay of the political machine. The vote of the "Pennsylvania Dutch" led by George Leib first began the political machine of Pennsylvania in the first decade of the nineteenth century and in the same decade Tammany began on Manhattan Island. In New England, the Pilgrim, taught by his twelve years in Holland began the general education of the immigrant. The Hollander failed to profit by the examples of his own ancestry. The German immigrants from the Palatinate and the valley of the Rhine were not only set apart by that greatest of all obstacles to the education of the immigrant, a separate tongue, but the public schooling of Pennsylvania itself was late and inferior. The negro slave who furnished the labor of the South was cut off from all education save in manual training. The failure to educate this immigrant in any way and his deprivation of personal rights and personal liberty by a strained legal decisionthe first but alas not the last to use American courts to narrow general rights instead of widening or defending them-laid the foundation of the political evils of the South today.

The fathers ate the sour grapes of ignorance, oppression and spiritual 
quiescence and the children's teeth were set on edge. All the evils we have today from the lack of the political education of the immigrant have their seed and root in the colonial period just as the best of our history today is founded on the spiritual independence of the Pilgrim and Puritan in New England and the constitutional independence of the Virginian.

Each race, as we at once see, in the Colonial period brought forth the fruit of the political education of the immigrant each after its own kind. The Pilgrim, the Puritan, the various types of the English which filled New England had in England the political education of the dissenters, chiefly Separatists and Independents, with like groups. Each had shared the struggle for two centuries or more before leaving England of the trade guild, the burgess, the forty-shilling free-holder and the small landholder, now returning to his own again in England. This background led in due order to the New England town-meeting and the General Courtwith an emphasis on the General-and an inheritance of the political opinion which made Cambridge University the home of causes, still living in America, and Oxford, the home of causes long lost even in England. Virginia had a larger proportion of those who by lineage, near or distant, represented the class struggle of the Baron at Runnymede. This early victory-at the very period when the immigrants to New England were receiving the political education in England which drove them to a new schooling in the new world-shaped in 1628 the first Bill of Rights (3 Charles I. c. 1). This broadened in sixty years to the enactment of 1689 (I William \& Mary, sess. 2 c. 2). Exactly as the impulse to selfrule gave the Pilgrim Covenant, so the historic Bill of Rights which has eclipsed the earlier statute of Charles laid the foundations of our American Constitutional restrictions on arbitrary power as first built upon by Virginians in our Constitution.

The political education of the early American immigrants in the seventeenth century went on apace in the eighteenth century because of their early training for four centuries from 1215. The German immigration to Pennsylvania, made up in a distressingly large fraction of those adscripti glebae, had no such hinterland and remains docile and submissive. The Dutch immigration had a like stability and is well illustrated in the century long Democratic allegiance of a tract like Schoharie County. From this tract, Dutch Schoharie, Albany, Renssalaer and Columbia Counties, came Van Buren to form as a leader the connecting link between the early Dutch democracy of New York State and the Irish democracy which has so often dominated the last century of New York State democracy.

The Irish, when they came to this country, driven out by the potato famine, were at the clan or tribal stage of development and they organized New York City on a tribal basis. In six years, 1847-1852, over $1,000,000$ Irish came to the United States. When I was exploring as a young reporter, twenty-five years later, the political jungle of New York City, I was struck at the resemblance between the political organization of Tammany and the tribal conditions I had seen as a boy in Kurdistan and the Arab marches of Mesopotamia. The chiefs were much alike, often able and always heavy-handed. There were the same uncertain and hostile boundaries between tribes. "Better not say you have been here, my boy," was one kindly warning, "or the Far-downers in the next ward may put a head on you." A predatory atmosphere was 
all about. There were groups of tenements all of whose inmates came from some one district in Ireland and feuds that went back to the Norman Pale were preserved. Irish was still heard. Tammany educated the Irish vote, but it was tribal Ireland which reorganized on a tribal basis the secret society Burr organized and Van Buren used.

The next immigration was the German vote $-1848+$, docile by nature, however republican in inspiration and their political organization turned on vereins and bunds innumerable which half a century later reorganized in a nation-wide federation so as to aid German despotism and have a Hohenzollern at its head in Prince Henry. The Italian immigration drawn in large part from the two Sicilies, one of the most murder-infected areas in Europe, was followed by a rapid increase in the murder rate of New York City. Educated by the Mafia at home, the Black Hand grew as the Italian immigration increased. With little and late tradition of voting in his early home before 1870, the Italian needed time to be educated to the ballot.

Slav and Magyar had not even shared the traditions of Rome and knew no Roman institutions until the sixth or seventh century. They were still farther removed from democratic institutions. They had never in their whole descent been, in any proper sense of the word, self-governing, save through an upper class. The Jews who came here knew little of civil organization except in that admirable school of self-sacrifice and self-rule, the Synagogue. This was far more of selfgovernment than had the Slavs of Central Europe about them or any Christians in the East of either the Latin or the Greek rite.

Exactly as the first advantage in the political education of the seventeenth century immigrant lay in the political estate which was probated in the cabin of the Mayflower as the heritage of $105,000,000$ today, so the past political education of the great mass of the immigrants of the twentieth century is the great obstacle to their political education now. With each successive wave of immigration we receive those who are less and less educated in any knowledge or experience of self-government. This is the full, convincing and sufficient reason why we must address ourselves to the exclusion of the illiterate and provide for the compulsory education in political knowledge of those who come in the future.

This compulsory education can not at best be more than a way prepared, by which the immigrant will be able to rise to the apprehension of the true America to which he has come--an America of standards of living as well as of principles of liberty; a land which in nearly all its states, save a few in the South, and in all its national feeling, regards the education of the child as more important than the work of the child in supporting its parents; a country which has in its constitution provided for the consideration of any change which anyone proposes in the fundamental law and by consequence in the statutes and administration of the Republic, provided these changes are sought by peaceful means and, at last, receive the approval, by vote, of a majority of Americans.

These fundamental concepts of social and political progress are not nearly as fully comprehended as they should be by those who are born in the United States and educated in its schools. They can never be acquired by the immigrant unless the immigrant has mastered the language of the United States. He can not be at home in this country, neither can he understand it so long as he reads only newspapers and books in a language not American. 
His ideas and education will always be non-American and too often antiAmerican, if he reads only a foreign press, however sincerely its editors may desire it to be patriotic and American. The language bar will be the most serious difficulty in learning his new home. He will accept orders from above which make him the ready prey of the political machine because he has been schooled to obedience in the land of his birth. The newspaper in his own language he needs for many reasons; but American he will not be until he speaks American. Here his effective political education must begin. This will enable him to secure the American view of the household which does not look to the support of the family by the children as soon as they can work. Yet when the law shifts the year at which they can work to fourteen, the immigrant in a large number of cases still continues to demand the labor of the child after that date. This is also true of many American families, particularly in rural tracts where the high school is distant and the labor of the farm calls for the child. Both groups are wrong, but work begun at fourteen by the child of the immigrant in the city, in the factory village or in the swarming dwellings of an iron and steel plant is, for obvious reasons, a more serious peril to the full Americanization of the child than labor on a farm, north or south, east or west.

The child of foreign parents suffers the more, first and chiefly, because the unconscious training and education in American institutions and American life go on for the child on our American farm more efficiently than in an immigrant tenement. Where the farm district is covered by Swedes, Germans or other immigrants speaking their original tongues and in two western states training their children in schools using these tongues, the child is not
Americanized as the revelations of the past five years have shown.

Farm or factory, meadow or mine, country or city, it is always true that the immigrant who continues to use his own original language is barred from full acquaintance with his new home. He is unable to read sanitary notices and warnings and he spreads disease. He causes accidents because he can not read safety signs. $\mathrm{He}$ never learns American law and tracking crime or criminal becomes a thousand-fold more difficult where any foreign quarter continues the use of its home tongue. The duty of a citizen can not be fully learned. All politics are filtered through alien channels, whether newspapers or politicians.

This is practical treason to American ideals, aims, principles and allegiances. No country can be united when it permits this disunion of tongues. For those born abroad, this barrier to a united land in 1910 included 2,930,373 persons over ten years of age speaking no English and it had grown one and a half fold (142.6 per cent) in ten years from 1900 to 1910 . The number is probably $4,000,000$ in 1920. This share of foreign born who could not speak English was in 1920 one-fifth of the foreign born over ten years in the cities and one-quarter of the foreign born of this age in rural communities. In 1920, New York had 421,951 who were ten and knew no English, Chicago 184,884 and Philadelphia 68,228. From 1900 to 1910 , New York had nearly doubled this undigested mass, Chicago had seen it grow two and a half fold and Philadelphia nearly trebled it. In New Mexico, a third of the native population speaks only Spanish. The political education of $14,000,000$ of foreign born in the United States can never be accomplished when over a fifth of them know not American. Until this is 
cured, the foreign born will remain by nature foreign born. Sentiment may plead for the memory of the country of origin. Material profit may ask for cheap labor. All the experience of the past and all the facts of the present prove the peril of this alien, undigested mass, indigestible until it speaks English.

The longer reform is postponed, the worse the situation will be. The obstacles are many. The mere number daunts any attempt to attack this evil thus far. The non-English speaking horde steadily pours in. Treaties are in the way, made when this evil did not exist and our immigration was in larger measure from the United King- dom. These treaties must be denounced and laid aside for all. The cost of teaching the tongue of the immigrant's new home can not be met by state expenditure. The federal government alone has the means and the power to act over the whole country. If American be required within a reasonable period under gain of deportation, the evil will first diminish and then disappear. The federal government working through state schools can accomplish the task in a decade. Unless it is taken up, crime will increase, ill conditions grow and our politics will be cursed in the future as in the past by non-American speaking citizens and foreigners. 